University of Wollongong

Research Online

Faculty of Social Sciences - Papers (Archive) Faculty of Arts, Social Sciences \& Humanities

2014

Arts-science collaboration, embodied research methods, and the politics of belonging: 'SiteWorks' and the Shoalhaven River, Australia

Leah Maree Gibbs

University of Wollongong, leah@uow.edu.au

Follow this and additional works at: https://ro.uow.edu.au/sspapers

Part of the Education Commons, and the Social and Behavioral Sciences Commons

Research Online is the open access institutional repository for the University of Wollongong. For further information contact the UOW Library: research-pubs@uow.edu.au 


\title{
Arts-science collaboration, embodied research methods, and the politics of belonging: 'SiteWorks' and the Shoalhaven River, Australia
}

\author{
Abstract \\ Arts-science collaboration is gaining increasing attention in geography and other disciplines, in part due \\ to its ability to 'do' social, cultural and political work. This paper considers the work of SiteWorks, a series \\ of projects initiated by Bundanon Trust - an Australian public company. SiteWorks involves arts \\ practitioners, scientists, other scholars and local people creating works in response to the Bundanon site, \\ on the Shoalhaven River, southeastern Australia. The paper draws on my experience as a SiteWorks \\ participant, and poses two questions. What does this arts-science collaboration contribute to an \\ understanding of the more-than-human world of this site? What are the methodological implications of \\ the collaborative, embodied research methodology? The study finds that SiteWorks informs a politics of \\ belonging. Understanding belonging has implications for thinking and action towards plant and animal \\ life, and for the highly contested realms of human identity, indigeneity and migration. Unsettling fixed \\ notions of belonging is essential for learning to live with the contingency presented by contemporary \\ environmental change. Here I propose a 'passing-through place'; a place not permanently dwelt in but vital \\ nonetheless. Secondly, the study finds that collaborative, embodied research methodology reveals and \\ challenges our practices, invites new modes of investigation, and presents new questions and insights \\ into place and practice. Embodied methods heighten awareness of the more-than-human world, \\ presenting opportunity for more ethical co-existence. The academy is presently witnessing increasing \\ attention to impact and non-traditional output. Despite ongoing challenges, collaborative, embodied \\ research practice presents one avenue for attending to these imperatives.
}

\section{Keywords}

science, embodied, methods, politics, belonging, siteworks, shoalhaven, collaboration, river, arts, australia, research

\section{Disciplines}

Education | Social and Behavioral Sciences

\section{Publication Details}

Gibbs, L. (2014). Arts-science collaboration, embodied research methods, and the politics of belonging: 'SiteWorks' and the Shoalhaven River, Australia. Cultural Geographies, 21 (2), 207-227. 
Gibbs, L. 2014 Arts-science collaboration, embodied research methods, and the politics of belonging: 'SiteWorks' and the Shoalhaven River, Australia Cultural Geographies 21(2) 207-227. DOI: 10.1177/1474474013487484

Accepted March 2013

Leah Gibbs

Australian Centre for Cultural Environmental Research

University of Wollongong

NSW 2522

Australia

leah@uow.edu.au

\begin{abstract}
Arts-science collaboration is gaining increasing attention in geography and other disciplines, in part due to its ability to 'do' social, cultural and political work. This paper considers the work of SiteWorks, a series of projects initiated by Bundanon Trust - an Australian public company. SiteWorks involves arts practitioners, scientists, other scholars and local people creating works in response to the Bundanon site, on the Shoalhaven River, southeastern Australia. The paper draws on my experience as a SiteWorks participant, and poses two questions. What does this arts-science collaboration contribute to an understanding of the
\end{abstract}


more-than-human world of this site? What are the methodological implications of the collaborative, embodied research methodology? The study finds that SiteWorks informs a politics of belonging. Understanding belonging has implications for thinking and action towards plant and animal life, and for the highly contested realms of human identity, indigeneity and migration. Unsettling fixed notions of belonging is essential for learning to live with the contingency presented by contemporary environmental change. Here I propose a 'passingthrough place'; a place not permanently dwelt in but vital none-the-less. Secondly, the study finds that collaborative, embodied research methodology reveals and challenges our practices, invites new modes of investigation, and presents new questions and insights into place and practice. Embodied methods heighten awareness of the more-than-human world, presenting opportunity for more ethical co-existence. The academy is presently witnessing increasing attention to impact and non-traditional output. Despite ongoing challenges, collaborative, embodied research practice presents one avenue for attending to these imperatives.

\section{Key words}

art; arts-science collaboration; belonging; embodied method; embodiment; interdisciplinary; more-than-human; nature 
Arts-science collaboration, embodied research methods, and the politics of belonging: 'SiteWorks' and the Shoalhaven River, Australia

We met at a bend in the river. The Shoalhaven River, in coastal southeastern Australia. The weekend ahead would be an introduction to the site, to each other, and to SiteWorks. Our work would involve walking, listening, tasting, traveling on the river by boat or raft, stacking lucerne bales, writing, photographing, gathering plant bodies, processing clay, projecting voice across the water. SiteWorks is an ongoing series of collaborative projects coordinated by Bundanon Trust - an Australian public company dedicated to the promotion of arts practice, education and enjoyment ${ }^{1}$. SiteWorks participants include arts practitioners, scientists and scholars, who work on site-based projects in response to the Bundanon Trust properties, Bundanon and Riversdale.

This paper draws on my experience as a SiteWorks participant to explore the possibilities of collaborative, embodied research methodology. The paper traces the form, method, and outcomes of SiteWorks to consider two sets of questions. First, what does this collaboration reveal about place? What does the collaborative project contribute to an understanding of the more-than-human world of the site? Second, what are the methodological implications of the project? What is the significance of a collaborative, embodied research methodology for understanding place? 
Arts-science collaboration is gaining increasing attention in scholarship across a range of disciplines. Within geography, arts-science - or arts-geography collaboration is adopted as both research strategy and focus of critique ${ }^{2}$. Two key ideas emerging from this work are the ability of arts-science collaborative practice to engage diverse publics ${ }^{3}$, and to 'do' social, cultural and political work $^{4}$. In the contemporary context of climate change, these functions become particularly important for understanding and developing new responses to changing environments. Gabrys and Yusoff ask: 'How do the shared encounters of arts and sciences with climate change also give rise to new understandings and capacities within and across these disciplines?'5 Head argues that insights from both the arts and sciences will be needed to overcome the damage wrought by the Anthropocene. But she urges against modernist metaphors of 'building bridges' across disciplinary divides; calling instead for 'plunging into the river together, rather than attempting to bridge $i^{\prime}{ }^{6}$. There is indeed space for exploring the practical and political possibilities of arts-science collaboration.

Some of the key insights emerging from this field are the methodological challenges of interdisciplinary work. Interdisciplinary collaboration has stimulated critical reflection on practice. Authors highlight the importance of learning from the techniques, protocols and rhythms of work of one's collaborators, and a willingness to unsettle prescribed or presumed disciplinary roles $^{7}$. 
In a parallel development, a growing number of scholars from a widening range of fields are exploring the possibilities and implications of embodied research methods; of the body as 'instrument of research'8. These two fields come together where arts-science collaboration uses and/or considers embodied practice ${ }^{9}$. Geography has a long relationship with the arts; particularly the visual arts. In recent years geographers have turned their attention to a broader range of arts practices and approaches to collaboration. And yet, Hawkins points to the still 'relatively underexamined questions of practice and embodied experience'. She expresses a need 'to explore not only art as "finished" object, but also to think about artworks as ensembles of practices, artefacts, performances and experiences' 10 .

Some notable examples certainly exist. Patchett and Foster ${ }^{11}$ push this agenda significantly in their treatment of the 'work' of taxidermy. They draw on their respective practice as geographer and artist to better understand taxidermy; to consider what a zoological specimen is and how it can be used. Together they focus on embodied practice and dynamic process - of all stages of making a specimen and of art-geography - to 'subvert the archive's claim to authenticity'12 and to encourage exploration in their viewer. Through careful attention to practice they challenge the priority given to the end product - to representation - and instead focus on the 'work' of taxidermy (and of collaboration) 'to show how specimens have been entangled "in life" as well as how we have creatively taken part in their "afterlives"'13. Hawkins' point however, that questions of 
practice and embodied experience remain 'relatively underexamined', has some credence. This paper seeks to contribute to this agenda.

These developments - in arts-science collaboration and embodied research methods - exist in the context of contemporary debates within the academy about research impact, engagement with publics, and non-traditional outputs ${ }^{14}$. Indeed, Tolia-Kelly ${ }^{15}$ identifies a 'neo-visual turn' in cultural geography that represents 'a new disciplinary orthodoxy' and a drive towards such imperatives. Collaborative, embodied interdisciplinary projects such as SiteWorks present an opportunity to attend to these priorities, as well as presenting alternate modes of knowledge production, research, and politics.

Through an analysis of SiteWorks, this paper makes two arguments. First, SiteWorks reveals themes that inform the politics of belonging; a deeply political notion in Australia. Second, collaborative, embodied research methods reveal and challenge our research practices, invite new modes of investigation, and present new questions and insights. In the sections that follow I introduce Bundanon, as both a site and an institution. I then discuss the beginnings and development of SiteWorks as a Bundanon project, and SiteWorks 2010 in particular. The next sections form the substantive discussion of the paper. 'SiteWorks and the politics of belonging' explores what is revealed about the more-than-human world of the site through the project. The penultimate section 
'Three glimpses of the river: collaborative, embodied research methodology' considers methodological implications.

\section{Bundanon, Arthur Boyd and the arts}

'Bundanon' - the site of this work - sits at a bend in the river. The bend coincides roughly with the upper limits of the tidal reaches of the Shoalhaven River; a large and relatively unregulated river on Australia's southeast coast. There is a dam upstream - Tallowa Dam - but for much of its length, the surrounding slopes are forested; dry sclerophyll and rainforest on Illawarra sandstone. Historically, early European timber-getters stripped floodplains of valuable red cedar (Toona ciliata). The bare floodplains now host dairy and beef cattle farms, and the odd camp ground, but they are few in number. Bundanon Trust manages three adjacent properties, two of which - Bundanon and Riversdale - are open to the public. The Bundanon property sits on the floodplain and comprises an historic homestead, Artist-in-Residence complex, offices and shop, and beef cattle property. A little way downstream Riversdale occupies the slopes of the valley, and incorporates the Boyd Education Centre, and offices situated within an historic homestead.

Bundanon was a gift to the Australian people from Arthur and Yvonne Boyd. Arthur Boyd (1920-1999) is certainly one of Australia's best-known artists. Much of his work considers the Australian landscape and the discordant place of Europeans within. His Shoalhaven paintings are considered by some to be among 
his best. They capture the intense light, and the 'knife-edge clarity' of tonal range in this landscape ${ }^{16}$. They play with the stark contrast between 'the mandominated agricultural flats and the primordial or primeval backdrop of the bushy mountain and rock'17. These are works characterised by themes that are universal, set within a landscape that is unmistakably the Shoalhaven ${ }^{18}$. According to John Walsh, emotive subjects and intimate details of landscape are tools with which Boyd communicates his 'affinity with the plight of this land and the injustices that pervade civilisation'19; strong themes also picked up by SiteWorks participants.

Arthur and Yvonne Boyd fell in love with Bundanon on a weekend visit to friend and then owner Frank McDonald. They bought neighbouring property Riversdale in 1974 and Bundanon in $1979^{20}$. Purchasing the properties allowed Boyd to 'pursue his wish to save the land and his family history: his mother's paintings, his father's drawings, his grandparents' drawings and paintings', sculptures and pottery made by his siblings, uncle, and other friends and family members; Arthur himself described it as 'quite a swag of booty'21. From the beginning, Boyd had some thought of giving the property away. He is often quoted as saying that one can never own a landscape. In his mind, landscapes, like houses and paintings, could be destroyed; the only way of assuring their protection was to give them away ${ }^{22}$. He tried to gift the properties to the Australian people for ten years, but the legal and administrative barriers were tremendous; almost insurmountable. Finally in 1993, Labor Prime Minister Paul Keating accepted the Boyds' gift on behalf of the Commonwealth and 'the people of Australia'23: the 
Bundanon site, including homestead, the Riversdale site, and a large collection of artworks, antiques and archival materials.

The Boyds' intention was that the property be protected, but open to the public. Bundanon Trust, established by the Keating government in 1993, works to fulfill the Boyds' vision of the place; that is, to:

promote arts practice and enjoyment by making the Bundanon properties a living arts centre for the creation and presentation of visual arts, writing, music and other performing arts, and the promotion of education and research in the arts. By conserving and preserving the natural and cultural heritage, and providing access to Bundanon and the Shoalhaven River, the Bundanon Trust will encourage an appreciation and understanding of the importance of the landscape in the lives of Australians ${ }^{24}$.

The Trust achieves this aim through an Artist-in-Residence program, residential education program for children and adults, concerts, special events, and open days, all conducted on the properties, in the Artist-in-Residence complex, the Ramsay Study Centre, and the Glenn Murcutt designed 'Arthur and Yvonne Boyd Education Centre'. The Trust cares for more than 4000 artworks and objects, the Bundanon homestead and Arthur Boyd's studio ${ }^{25}$. 
The Boyds brought this place to the public, but the Boyd history of Bundanon is relatively short. There are numerous histories of this place upon which artists draw for their work, and stories that live on through being re-told by Bundanon staff, volunteers, and other Boyd and Bundanon enthusiasts. Some are recorded in books and other documents including the Heritage Management Plan ${ }^{26}$. It is this layer of stories that makes this place what it is. And the layer of stories provides material with which SiteWorks engages and responds.

\section{Ten Trenches, SiteWorks and collaboration at Bundanon}

In 2008 Bundanon Trust initiated a partnership with the University of Wollongong's Faculty of Creative Arts and School of Earth \& Environmental Sciences. The partnership involved a creative development project Ten Trenches, led by brothers Michael and Tim Cohen ${ }^{27}$. Michael is a performance artist and artistic director; Tim a fluvial geomorphologist. Tim is interested in the flood history of the Shoalhaven River, and what it might tell us about the future of climate-driven sea level rise. His research at Bundanon aims to develop a record of the river's flood history, and involves drilling auger holes and slot trenches in the flood plain to construct that history ${ }^{28}$. Tim's motivation to collaborate with artists at Bundanon was born of a frustration at the 'dumbing down' and miscommunication of climate science in the media. In Ten Trenches, Michael Cohen was intrigued to learn how he and his colleagues might respond creatively to the scientific questions and research practices on the floodplain. 
Ten Trenches included an open day at Bundanon combining the science of sealevel change (long term and anthropogenic), exploration of arts-science collaboration, and performance involving dance, lighting and music set amongst the trenches, auger holes and earth mounds. The performance investigated 'possibilities, revealed and imagined, on the Bundanon floodplain'29. Ten Trenches demonstrated interest in and potential for combining arts and scientific research at Bundanon. It seeded a broader program - SiteWorks - with the aim of connecting diverse arts and environmental research teams working on site, and strengthening the relationship between Bundanon Trust and the University of Wollongong.

Trust promotional material explains that for decades artists have responded to the profound beauty of the Bundanon landscape. Scientists, historians, archaeologists and local people have also explored the environment and contributed to our knowledge of this very special place. In 2010 SiteWorks will bring artists and scientists to Bundanon to continue these investigations ${ }^{30}$.

SiteWorks coordinators stated that as 'both science and arts practitioners are interested in engaging more critically with the broader community, we wanted to explore potential for collaborating with audiences' ${ }^{31}$. As such, the SiteWorks coordinators developed the project to include space for creative work in a supportive peer group environment (the 'Lab') and to engage a broader audience in ideas and conversation (the 'Forum'). In SiteWorks 2010 a wider group of 
participants was invited to continue the collaborative relationship on site that began with Ten Trenches.

\section{SiteWorks 2010}

SiteWorks convenors - Fiona Winning, Michael Cohen and Deborah Ely describe the project as an experiment, and a collaboration between participants, convenors and Bundanon staff. They designed an open process, in which they took responsibility for initial framing of ideas, overall structure, and event management, and the precise shape of the project was allowed to evolve on site in a responsive and reflexive way. Bundanon staff were responsible for providing cultural, site-based and logistical support, though actual involvement far exceeded this remit. Participants brought experience and expertise from a wide range of fields, including dance and performance art, music and sound art, photography, a range of visual arts, human geography, geomorphology, ecology, environmental and community activism. We were set the task of being open to collaborating; to allowing the process to shape and take shape through our responses to place.

Our introduction to Bundanon in August 2010 comprised three walks: a river walk with Richard Scott-Moore and Cecil McLeod, indigenous songmen of the Shoalhaven region and dancers with Doonooch Dance Company; a sound walk to the forested amphitheatre with sound artist Nigel Helyer; and an escarpment walk with Bundanon property manager, Henry Goodall. Each showed a different 
aspect of the property, and told different stories of place. In their welcome to country, Cecil and Richard explained that through being on the riverbank, hearing part of the Dreaming of the river, we were now part of that story. The three walks together formed initial stimuli for our own responses to the site.

Five weeks later we met again for the 'Lab': a structure familiar to many arts practitioners, but perhaps less so to other scholars. This intensive 10-day residency format allowed time for participants to develop trust, to get to know each other's work and practices, and for discussion and private reflection. Foster and Lorimer ${ }^{32}$ discuss the importance of this process of 'Learning about others' protocols, techniques and skills'; a process enabled by a range of interactions, which for them has included ongoing conversations, sharing of ideas and values, favourite books and sources, and a formal residency. They speak of the significance of “"noseying about" in others' worlds'33, discuss 'how different rhythms and routines for work were set', ${ }^{34}$ and consider how this allowed them to discover 'respective modes of working that seemed to share a methodological sensibility'35. In SiteWorks, cooking and eating together, as well as working during the day and evening fostered highly productive and extremely enjoyable working relations. Through each day we worked alone or in groups, we crossed paths and shared news of the progress of our works, we helped source or lug equipment. 'Collaboration' was broadly realised. Some individual works were created through direct collaboration; others were ostensibly independent. But all grew from the broader collaborative process. The Lab involved a wide range of methods and practices, including all manner of embodied and sensory activities: 
gathering edible weeds and local plants, digging and processing clay, exploring the river by boat, photographing, walking, talking, touring the historic house, discussing logistics, digging a trench, cutting lantana, writing, reading, weaving, identifying bird calls, exploring the archive, observing the bower bird that lives in the homestead garden. Participants responded to particular places and elements of the site - the river, the birds, the question of the site's indigenous history. Through all of these actions and conversations our work was informed.

Bundanon staff offered more than the logistical and site-based 'support' promised. They participated enthusiastically in the project, working far beyond formal job descriptions in order to design and build an invisible raft that would float safely on the river (Figure 1); drag that raft along the river bed under cover of darkness; construct three-dimensional letters in a paddock from lucerne bales, star pickets, bamboo poles and cable ties (the former would feed the property's cattle after the event) (Figure 2). The collaboration came to involve Bundanon staff as indispensible participants, rather than simply support. Roles shifted and changed through the process.

[Insert Figure 1, Figure 2]

The weekend ‘Conversation' following the Lab comprised Field Day and Forum. The Field Day, held at the Bundanon property, was an opportunity for 
participants to share their work with the public. It was advertised locally and through Bundanon Trust's networks. The audience was extremely open; it was not entirely clear what they were to be part of until the event began. The willingness of the audience to be taken on a journey exploring and engaging with the site made the event possible, and made it work as well as it did. The Forum was held the following day at the Boyd Education Centre at Riversdale. Invited scientific and local experts spoke, while the audience sat in tidy rows of chairs. Speakers discussed topics including: the Shoalhaven River's history, health and place in the community; current challenges to water quality, biodiversity, and bank erosion; the future of food security, including sustainable agriculture and aquaculture practices; and strategies for action in the face of climate change, including artist-led projects and collaborative processes.

The Field Day and Forum elicited rich outcomes and responses. In presenting two vastly different formats, they demonstrated two ways of understanding, responding to, and communicating about place; two ways of producing knowledge. The audiences on the two days overlapped but were not identical. The Field Day offered an unknown outcome (perhaps, it was suggested to me, a little too unknown for the tastes of some); the Forum provided a familiar setting, in which experts share their knowledge with a broad and mixed audience ${ }^{36}$. Together, the Field Day and Forum raised questions and stimulated discussion about the site, about environmental futures, and about the roles of the arts, arts institutions and relationships between arts and sciences in responding to environmental change ${ }^{37}$. 
In the sections that follow I explore two sets of response to, or outcomes of, SiteWorks. First, in 'SiteWorks and the politics of belonging' I consider what this collaboration reveals about the site; what the project contributes to our knowledge of this place. In particular, I suggest that the collaboration informs the notion of belonging; an idea that is deeply political in Australia. Next, in 'Three glimpses of the river: collaborative, embodied research methodology', I reflect on the implications of this methodology. I suggest that this approach exposes participants to a range of new methods and techniques, reveals and challenges our own practice, and in so doing invites new modes of investigation and presents new insights.

\section{SiteWorks and the politics of belonging}

Belonging is a deeply political notion in Australia. It is a pivot for debate and strong sentiment around indigenous relations, migration, and environmental management of plant and animal species and discourse of their place in Australian ecosystems. The concept of belonging influences policy and management programs. Yet belonging is highly problematic for a settlerdominated society, and attracts extensive research across a wide range of disciplines and traditions ${ }^{38}$. 
SiteWorks 2010 informed this politics of belonging through a number of individual responses. The introductory weekend at Bundanon presented two experiences of belonging in the form of the river walk and escarpment walk. Both expressed a sense of attachment to place, storied meetings at the river, a part of oneself and one's life enmeshed with the river. These walks became a strong focus of discussion and creation during the Lab, and formed the core of my own response. SiteWorks participants foreshadowed encounters between humans and between humans and plant and animal species deemed 'native' or otherwise. Language used to describe this latter category is revealing: terms include settler, introduced, exotic, alien, invasive, feral. But participants explored nuanced encounters. Not the simplistic binary relations of indigenous/nonindigenous, native/invasive. Rather, works questioned - and invited the audience to question - the subtleties of categories, relations and encounters.

Indigenous visual artist $\mathrm{r}$ e a made a work entitled 'maang: ceremony' (Figure 3). The word 'maang' - taken from her language group, Gamilaraay - translates as 'message stick'. The work is a response to the presence of Indigenous knowledge and loss of Indigenous languages in the landscape, and the artist's presence in country that is not her own. $\mathrm{r}$ e a 'offered this work/word in acknowledgement of this absence as a healing ceremony'39. It acts as a call for recognition, communication, healing, co-existence, and respect. The work involves vertical construction (by staff, the artist and other SiteWorks participants) of the word 'maang' in lucerne bales - a plant species introduced to Australia but deemed useful (indeed, Bundanon's Property Manager insisted on 
lucerne, as opposed to straw, as the building material so it could be used as fodder after the event). The letters are mirrored by dead lantana - another introduced species, this one deemed useless, and subject to an eradication program on site. The lantana letters are laid out on the ground in front of the lucerne, and the night's finale sees the lantana set alight.

[Insert Figure 3]

Diego Bonetto's 'Weeds “R” Us' unsettles categories of 'weed' and 'native' plant species. Bonetto contends that the plants and ecosystems of the site are disrupted but fertile, and provokes us to reconsider our interactions with plant life. He prepares various meals from plants collected on the property (both 'weeds' and 'natives'), and invites us to eat them (Figure 4). Participants experience the work through their bodies, smelling, touching, tasting, consuming, and rethinking the notion of what belongs ${ }^{40}$. 'Weeds "R" Us' speaks to the Australian fixation with categorising plant species as 'native' or 'weed'. And it invites us to explore our own place in the landscape, as humans, and for many Australians, as migrants. Weeds are all of us Bonetto says; 'masters in adaptation, ever searching to ecological pockets to establish themselves' ${ }^{\prime 1}$. The work presses us to think about the categories we choose to describe species; to recognise that we base our interactions and interventions on those categories. But weeds are, and co-existence therefore is, 'not a necessity, rather a matter-of- 
fact $^{\prime} 42$. So we need to shift our thinking and find new ways and means of guiding our actions.

[Insert Figure 4]

Questions of belonging in Australia are frequently configured around geographical origin ${ }^{43}$, divided into periods before and after European colonisation $^{44}$, and tied to notions of ecological restoration ${ }^{45}$. Yet Lesley Head suggests that we are currently in an era in which we must increase our capacity to deal with contingency and unpredictability'46. In this light, fixed notions of belonging should be unsettled; and they are through SiteWorks. The site and the project pose questions about the kinds of relationships with place that might constitute belonging.

A key characteristic of contemporary Bundanon is that this is a place that people pass through. Visitors to the historic house and property, artists in residence, education groups, employees, all pass through this place. We learn, make connections, but we do not dwell here. Arthur Boyd and his family, the people for whom this place is best known, lived here for only a short time, and claimed no ownership. Previous settler families similarly passed through. The notion of a 'passing-through place' presents a different way of thinking about belonging that is not based on fixity or longevity. It embraces impermanence and the 
importance of places that may not be permanently dwelt in, but are vital nonethe-less. It presents a lens through which to differently view relationships between places, people, and the more-than-human world.

Visitors to Bundanon frequently ask about the Indigenous and contact history of the site ${ }^{47}$. Likewise, SiteWorks participants were eager to learn more. There are strong living connections and oral histories associated with this place. Local elder Aunty Ruth Simms welcomed us to country at The Forum; local songmen Cecil McLeod and Richard Scott-Moore introduced us to the river during the introductory weekend and the Field Day; SiteWorks participant Jim Wallis and local Aboriginal artist Steve Russell held a weaving workshop using materials from the properties and early Aboriginal technologies to make fishing line, string, nets and containers. But despite these living connections, little is known of the Indigenous and contact history of Bundanon. We know that this place (like all of Australia) was taken through the process of colonisation, but under what conditions? In order to form relationships with place, visitors want to know something of this history.

In 2010 Bundanon Trust commissioned an Indigenous Heritage Management Strategy ${ }^{48}$. The purpose of which was to manage and protect the Indigenous heritage of the Trust properties, and to develop and share knowledge of the site. The heritage study identifies artefacts including stone tools and axe grinding grooves, but proposes that elevated areas of the wetlands and swamps of the 
Shoalhaven delta downstream are likely to have been the pre-contact centre of population. It is likely that this area was a place to pass through, the river being a transport corridor to food, resources, ceremony and ritual, rather than a place in which people settled ${ }^{49}$. The implications of this finding invite us, once again, to rethink the notion of belonging. What does it mean to belong to a place? Historic and contemporary relations with Bundanon suggest that a 'passing-through place' can hold deep significance; that the idea of belonging does not require settlement, permanence or fixity.

SiteWorks itself forms a fleeting set of relations with place. But such relations can be revealing. Morris and Cant, in their discussion of the temporary Hebden Bridge Sculpture Trail in Yorkshire (UK), 'explore the fluid, multiple and mobile understandings of site and artwork when placing sculpture outdoors ${ }^{\prime 50}$. They argue that 'art may stimulate and embody understandings of landscape, place and identity, across a range of transitory encounters that contribute to the telling of ephemeral and sometimes invisible stories connected to a site/artwork’51. Such transitory encounters were created at Bundanon in a variety of forms. The artworks are fleeting, but they are of this place, at times revealing stories less visible.

Perhaps the most striking element passing through this landscape is the Shoalhaven River. The river is an intrinsic part of this place. But the river - its waters, fish and other animal life, plant life, humans, all of which comprise it - is 
always passing through the landscape. The river is a 'water place', a site or path 'where water flows, sits, sinks, falls, emerges, passes through, and evaporates from, and where histories of interaction between humans, non-humans, water and landscape form places'52. Many of the works created as part of SiteWorks respond to the river, and reflect the passage of people, stories, and time through this landscape. Tess de Quincey’s 'Float - slipping through time' involves a performance on a barely visible raft floating upstream ${ }^{53}$. The work is choreographed and performed in the tradition of 'Body Weather', a style that explores the intersections of bodies and the environments they inhabit. 'Body Weather is a notion of omni-centrality ... A weather like contingent and everchanging relationship’54. The piece speaks of relations between humans and water and changing connections through time. The work is performed on the river, working with the elements of the place - tide, nightfall, vista, access for audience (a small beach on the inside bend) - and physically passes through the site. It is inherently of this place, and also speaks of more universal themes of the passage of time, change and impermanence (Figure 5).

[Insert Figure 5]

Robyn Backen's 'Last Word' draws on the 1931 diary of then Riversdale resident Jack Weir. Weir recorded in his diaries daily observations of the weather at Bundanon. This sound piece uses a play of disembodied human voices and the echo created by the valley. It gives voice to Weir's weather observations, and 
expresses something of the living history of the site ${ }^{55}$. Like the weather, people and their stories and connections pass through, but comprise place. Alex Kershaw's 'Through the River' involves video recordings of contemporary river users undertaking and/or discussing their 'quotidian rituals' along the river ${ }^{56}$. They express deep connection with the river; they visit regularly, to enjoy swimming, fishing, paddling, wake-boarding, and in so doing, re-inscribe their connections to place.

These works draw attention to vital connections with place that are based on fleeting relations, changing connections, sometimes interactions, re-inscribed encounters. Much contemporary debate around belonging in Australia is underpinned by fixed notions such as permanent dwelling, ownership, longevity or fixity. Unsettling these ideas has implications for thinking and action towards plants and animals, and for the highly contested notions of identity, indigeneity and migration in human society ${ }^{57}$. In the context of contemporary environmental change and uncertainty, fixed and flawed ideas of belonging must be challenged. Head suggests that living with the biotic and abiotic changes that have come with European settlement 'requires us to be open to the contingencies of both the past and the future'58. Ecologists including Hobbs and others ${ }^{59}$ speak of 'novel ecosystems': ecosystems characterised by novel combinations of species with the potential for new ecosystem functions, and by human agency. Environments are changing through direct and indirect human action. We cannot return them to some point in the past; efforts to do so are resource hungry and often futile. So we need to change our relationships with these altered landscapes. Both in terms 
of how we think about and how we interact with them. A related logic might be applied to human society and belonging: conditions change and with change our understanding of belonging must adapt. 'Passing-through place' draws attention to the limitations of an understanding of belonging based on permanence and fixity, and offers one avenue for reconsidering belonging in a way that is open and flexible. It highlights the need to adapt our understandings of how we live with other humans and a more-than-human world under changing conditions.

\section{Three glimpses of the river: collaborative, embodied research methodology}

This section asks what is the significance of a collaborative, embodied research methodology for understanding place? What are the methodological implications of the project? In this section I discuss the research practices undertaken through the project, and reflect upon my own experience of the collaborative process. I suggest that the coming together of diverse practices and epistemologies reveals and challenges our practice, stimulates new modes of investigation, and presents new insights into place, practice and methodology.

Exposure to the practices of others, and to the collaborative process itself, made me more conscious of, and then led me to examine and question, my own work practice. My initial response to Bundanon and SiteWorks was prompted by my interest in human relationships with water and the more-than-human world of rivers. I was interested in responding to the layered stories of the river - that 
dominant feature of the landscape. As the week of the Lab progressed, my experience of the collaboration itself deepened my interest in the methodology of the project. I quickly became as interested in how we do our work as the ideas we seek to explore and communicate. Foster and Lorimer discuss how their artgeography collaboration has 'challenged some of our assumptions and habits, and forced us to articulate something of the ongoing process of work, as well as some of our differences' 60 . They go on to suggest that 'Learning about others' protocols, techniques and skills can show up aptitudes you all too easily take-forgranted: illuminating the points and places from which research leads are taken; showing how seemingly disparate things are pieced together; and, how material builds, and gathers coherence or momentum'61. Similarly, Patchett and Foster make a case for 'reflecting upon the behind-the-scenes work we are all involved in', because the work itself, the research method employed, 'can have unexpected and transformative potency'62.

Part of the reason for such insight and transformation is that through collaboration roles become less fixed. Perdita Phillips describes the challenges of 'the ambiguous role of the artist as scientist, ethnographer and researcher', and reflects upon her own process of drawing on understandings and techniques from each of these fields to make her $\operatorname{artwork}^{63}$. Of the project 'The Lachlan: Blue-Gold', Sarah Ryan explains 'Artists and scientists, like the processes and influences of a river, have gone beyond defined disciplinary boundaries to share knowledges, perceptions and understandings'64. Such reflexive practice, 
openness to ambiguity, and willingness to challenge stable roles, enable us to learn from others' techniques and epistemologies.

Bodily and sensory practice is central to the SiteWorks collaborative methodology. I was struck by the extent to which my artist collaborators use the body and senses to explore and learn, as well as create and communicate. As a group we learnt through various interaction with the site, by gathering, digging, walking, rowing, lugging, listening. We engaged bodily with dirt, documents, river water, the homestead, echoes, cattle, people, weather, cameras, projectors, bird song. Our bodies became 'instruments of research'65, shaping our engagement with the more-than-human world of the site. This work revealed and challenged my largely taken-for-granted employment of, preference for, at times reliance on, the spoken and written word.

Engaging bodily with the site stimulates, as Gibson-Graham and Roelvink suggest, 'a process of learning involving a collective of human and more-thanhuman actants'66. Notably, birds became significant to the project. Nigel Helyer's sound walk, during our introductory weekend, heightened awareness of our surrounds. Participants walk blindfolded through a forested path and describe the sounds they hear. Birds feature strongly in our observations. Key encounters with birds become pivotal. They immerse us in place through sound and sight and the temporal aspect of the encounter: a raptor flying overhead, perfectly on cue as Cecil McLeod and Richard Scott-Moore welcome us to the river; the 
appearance of a Glossy Black Cockatoo - listed threatened species - among the casuarinas on Henry Goodall's escarpment walk, its bright orange tail feathers revealed as it flies from its perch. Conversations repeatedly turn to these affective bird encounters.

Local weaver Jim Wallis' encyclopaedic knowledge of the birds of the area and his ability to identify bird call is often called upon. It contributes to Barbara Campbell's performance piece 'call, recall, respond', exploring how humans are affected by birds on the site. This piece inverts the notion of humans as sole agent. It challenges the priority given to 'human impact' models for thinking about more-than-human interactions. Instead, this work considers how humans respond to and are affected by birds. The audience members, assembled in the homestead garden, are invited to don camouflage in the form of vegetation, while Campbell demonstrates use of her mobile 'hide', which she has constructed from plant materials gathered on site (Figure 6). Garth Paine's sound work 'Present in the landscape' uses an interplay of sampled dawn and dusk bird calls, human voices and musical instruments. Performed inside the homestead, this piece explores connections between experience of the landscape and domestic and daily life. These works urge us to learn 'to be affected as an ethical practice, one that involves developing an awareness of, and in the process being transformed by, co-existence'67. Embodied affective encounters and artworks invite us to be aware of the more-than-human others with whom we share the world. To observe - through being affected - and reflect upon how we might more ethically co-exist. 
[Insert Figure 6]

The embodied collaborative process challenged me to work differently. The methodology pushed and inspired me. It opened me to a wider methodological repertoire for research and learning, and for writing, all of which marked by embodiment. My research and writing practice were determined by the collaborative process: I wrote in garden, paddock, homestead kitchen, with pen and notebook, in small grabs and long periods, often outside in the spring air. Writing in situ made a difference to my writing practice and writing style, and continues to inform my practice. Following the SiteWorks Lab I have undertaken two two-week residencies at Bundanon as part of the Trust's Artist-in-Residence program. The residencies provide an intensive period to write and to conduct further research. They have granted me access to the property, art and archival collections, and the knowledge and experience of Bundanon staff. But more significantly, being on site has allowed me to get to know the place and its moods more intimately. Close observation and a physical relationship with place has become an important theme in my research and practice.

Hayden Lorimer writes of the complex relationship between fieldwork, archive and writing. He suggests that geographers have begun to recognise the power of story, 'ushering in more thickly descriptive - sometimes lyrical, highly decorative - prose', but notes that the 'fusing of poetics and politics' remains a significant 
challenge ${ }^{68}$. Hawkins ${ }^{69}$ likewise discusses the growing wealth of embodied writing practices within humanities and social science scholarship, exploring writing that is responsive to an argument, and is as such a performance of politics. It is my hope that this present work contributes to the bringing together of writing, story, poetics and politics. Importantly, in this case political agency involves the more-than-human; 'variously sized collectives of human and nonhuman actants ${ }^{\prime 70}$. As discussed in the previous section, the embodied collaborative process - comprising the more-than-human world of the site informs political concerns of significance in Australia and beyond. The collaboration itself forms part of a performance of politics, in which participants transform and are transformed by process and site.

The project also introduced me to a new audience - new people, purpose, context and location. My writing would be a reading; a performance on the Field Day. As such, I would pay attention to a different word count, rhythm, sense of purpose, audience members. Through my experience of SiteWorks and Bundanon, three stories - three glimpses of the river - became significant, and it was around these glimpses that I framed my writing response to the site (Figure 7). My contribution to the Field Day was a reading under the coral trees in front of the homestead. Setting was important. It allowed me to reference points of significance: the bend in the river; a jacaranda tree; the lime mortar of the homestead. 
[Insert Figure 7]

The Field Day audience, and indeed the SiteWorks project more generally, provide an opportunity to attend to the new challenges we confront in contemporary scholarship. With increasing demand for impact, public engagement and non-traditional outputs, we encounter new audiences, formats, expectations; our work demands new skills, methods, techniques; and we are invited to develop an alertness and responsiveness to new possibilities for political engagement. Collaborative, embodied research methodology provides one avenue for pursuing these new imperatives.

\section{Conclusions}

SiteWorks presents insights into the more-than-human world of the Bundanon site. In particular, the project informs the notion of belonging, a deeply political concept in Australia. The process and works created unsettle definitions of belonging based on permanence and fixity. In the context of changing environments, old fixed notions no longer work. Environments change, and so too should our idea of what belongs. In this context we need to learn to better live with contingency. To do so requires moving away from fixed notions and binary categories, such as native/exotic, to more subtle relations. How we understand belonging is important because our ideas shape policy and management strategies for the plant and animal world, and the highly contested terrain of human identity, indigeneity and migration. Unsettling fixed notions has 
implications for thinking and action across these realms. The concept of a 'passing-through place' highlights the importance of places not necessarily permanently dwelt in, but none-the-less vital. The broader implication for thinking about belonging is that other more nuanced relations for humans and the more-than-human world exist and can be imagined.

Collaborative, embodied research methodology is central to SiteWorks. Such practice encourages greater consciousness of one's own approach to research, and challenges sometimes taken-for-granted methodology. Engaging bodily with the site stimulates learning both about and involving more-than-human actants. In the case of SiteWorks, affective bird encounters became key, inviting us to invert the notion of humans as sole agent, and the priority given to the concept of 'human impact'. These encounters and the works created urge a greater awareness of the imperative for co-existence. Collaborative, embodied practice pushes researchers to work differently. For me, this has meant adopting new practices of writing and performance that allow close observation, physical relationship with place, and getting to know the moods of place. It is my hope that this process may contribute to a 'fusing of poetics and politics'71 that has at its heart the more-than-human world.

Finally, collaborative, embodied research provides an opportunity to attend to the new challenges of contemporary scholarship: the growing emphasis on impact and non-traditional output. Crucially, engaging with art is not simply an 
easy way of attending to the 'impact agenda'72. Rather, it presents a new purpose, audience, format and expectation. At the SiteWorks Forum I sadly heard repeated (just once) the oft-quoted idea that arts-science collaboration plays an important role because artists can communicate complicated science to the public. There is possibly some truth to this idea, and it may be the aim of some projects. But the significance of collaboration is far greater. Arts-science collaboration is not simply a means of communicating research truths. Rather, collaborative work - and particularly collaborative, embodied methodology makes a real difference to research practice and outcomes: it pushes us to reflect on assumptions of our own practice; calls for new skills, methods and techniques; opens possibilities for observing and for asking previously unimagined questions; and presents possibilities for political engagement and communication with new publics.

Institutional barriers and risks exist, such as funding opportunities, constraints on publishing, and differing demands on teacher-researchers and (often independent) arts practitioners. Work practices can present their own limitations to collaboration. Collaborative work is time-consuming, requiring investment in learning about others' practices, priorities, values and intellectual traditions. However, Dwyer and Davies ${ }^{73}$ note that despite pressures and limitations, 'innovative forms of methodological experimentation have been sustained, and have even prospered within this challenging research environment'. The work is challenging, but the rewards are great. Collaborative work can highlight issues significant to the politics of place. It can reveal and 
challenge our practice, and in turn stimulate new forms of investigation, leading to new and unimagined questions. These qualities become vital as we seek to learn how to live as part of a more-than-human world at a time of great change.

\section{Acknowledgements}

This research was supported by Bundanon Trust through the SiteWorks project and Artist in Residence program. Thanks to Bundanon staff; SiteWorks convenors Fiona Winning, Michael Cohen and Deborah Ely; my fellow SiteWorks Associates; and Heidrun Löhr for permission to use her photographs. Thanks also to Lesley Head, Chris Gibson and three anonymous reviewers for comments that significantly improved the paper. 


\section{Figures}

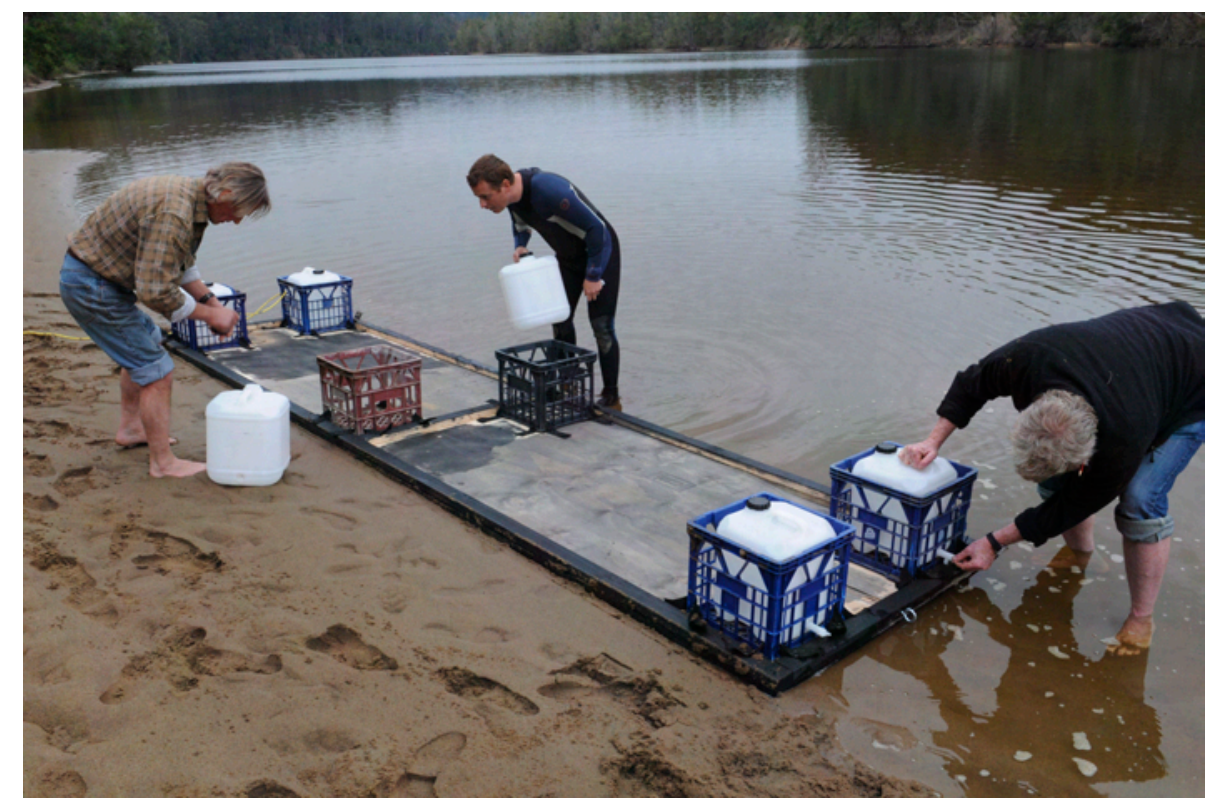

Figure 1: Constructing a raft on the Shoalhaven River. Photo by Heidrun Löhr, September 2010.

(Heidrun Löhr is a SiteWorks participant and photographer. She produced an artwork as part of the collaboration, and a photographic document of the event. I use her photographs here with her permission).

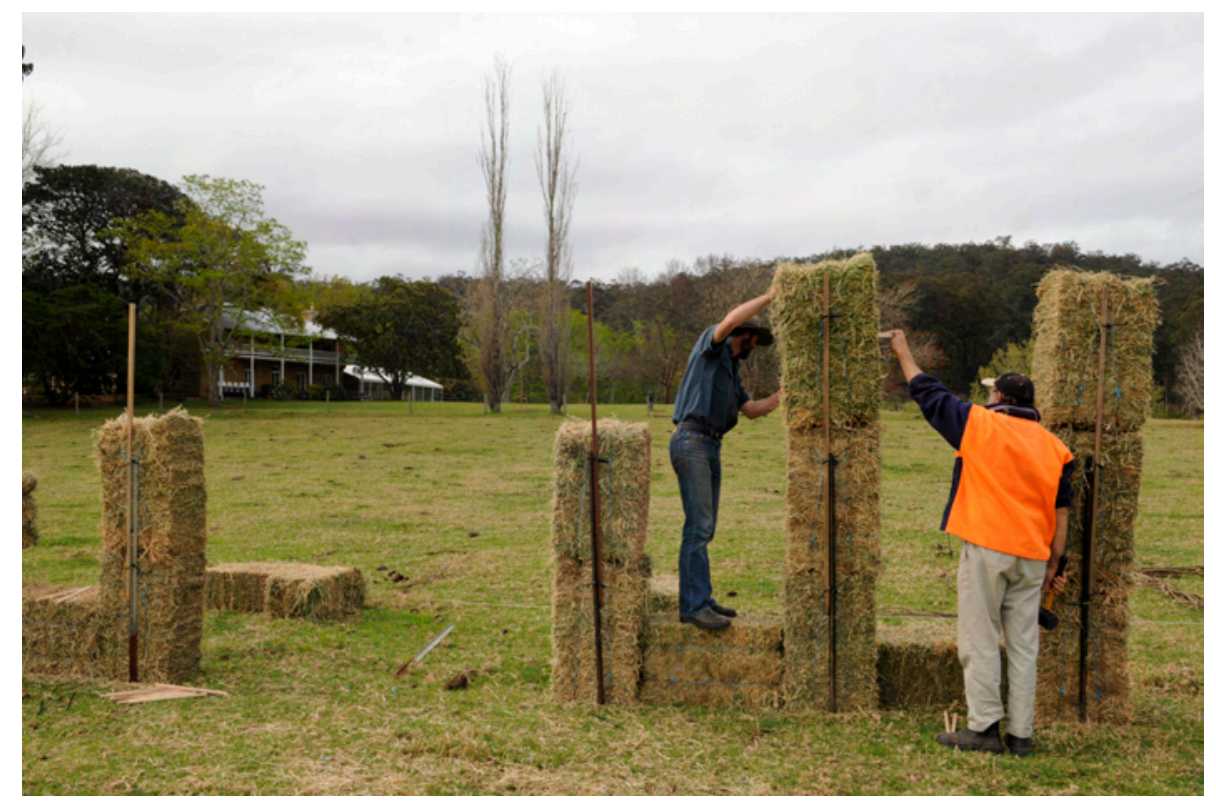

Figure 2: Assembling a work/word in a Bundanon paddock. Photo by Heidrun Löhr, September 2010. 


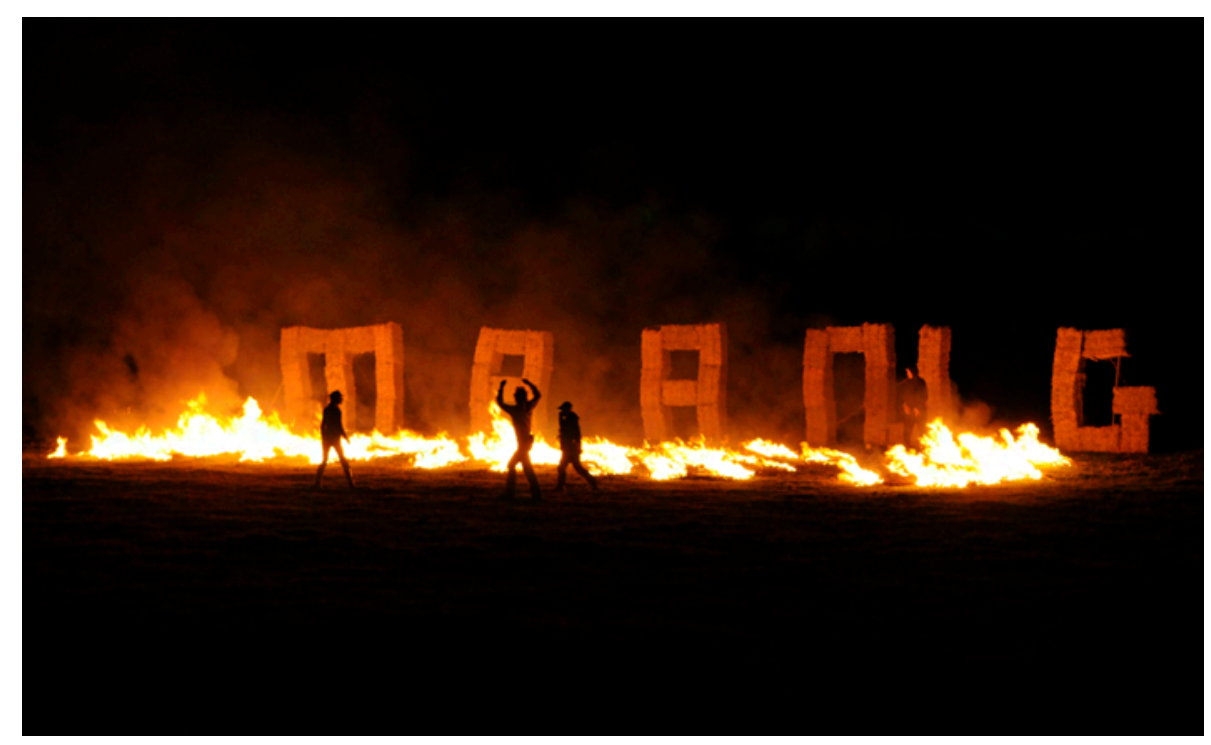

Figure 3: 'maang - ceremony (Gamilaraay)'. Artwork by r e a. Photo by Heidrun Löhr, September 2010.

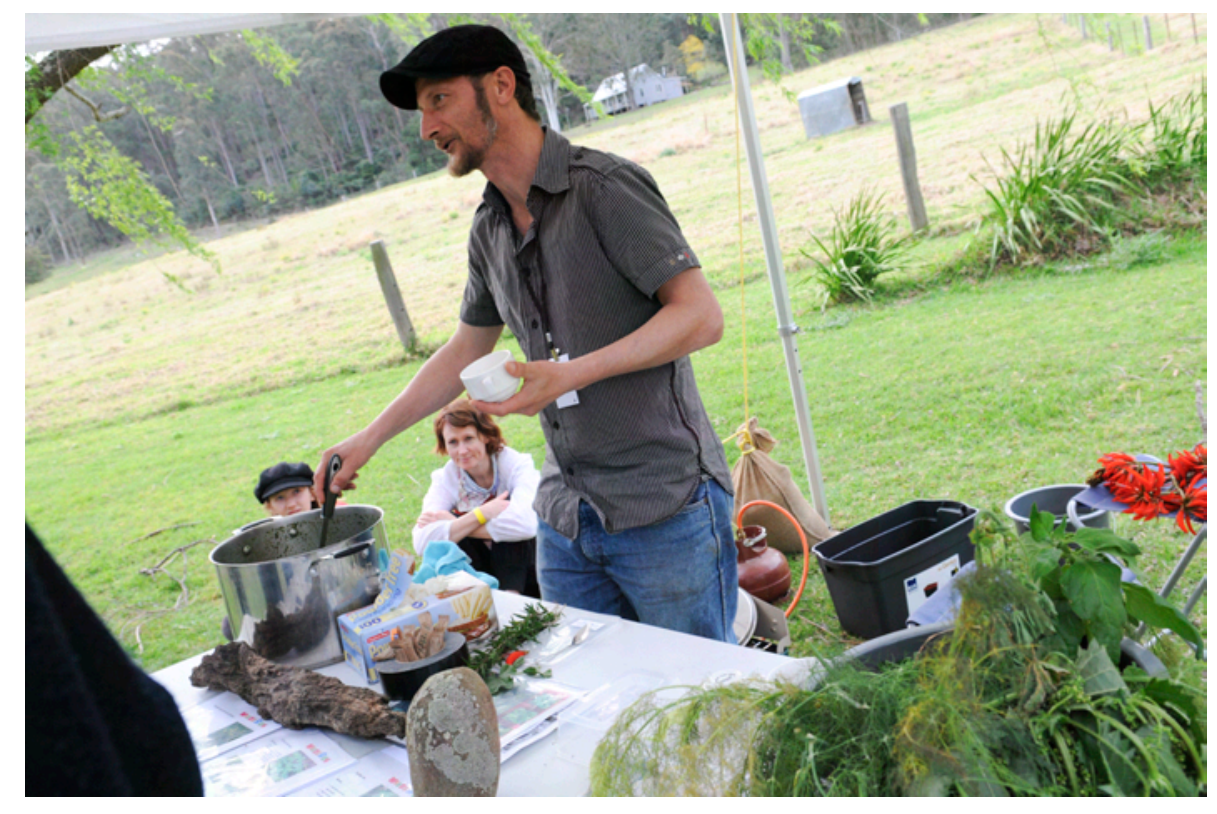

Figure 4: 'Weeds R Us'. Artwork by Diego Bonetto. Photo by Heidrun Löhr, September 2010. 


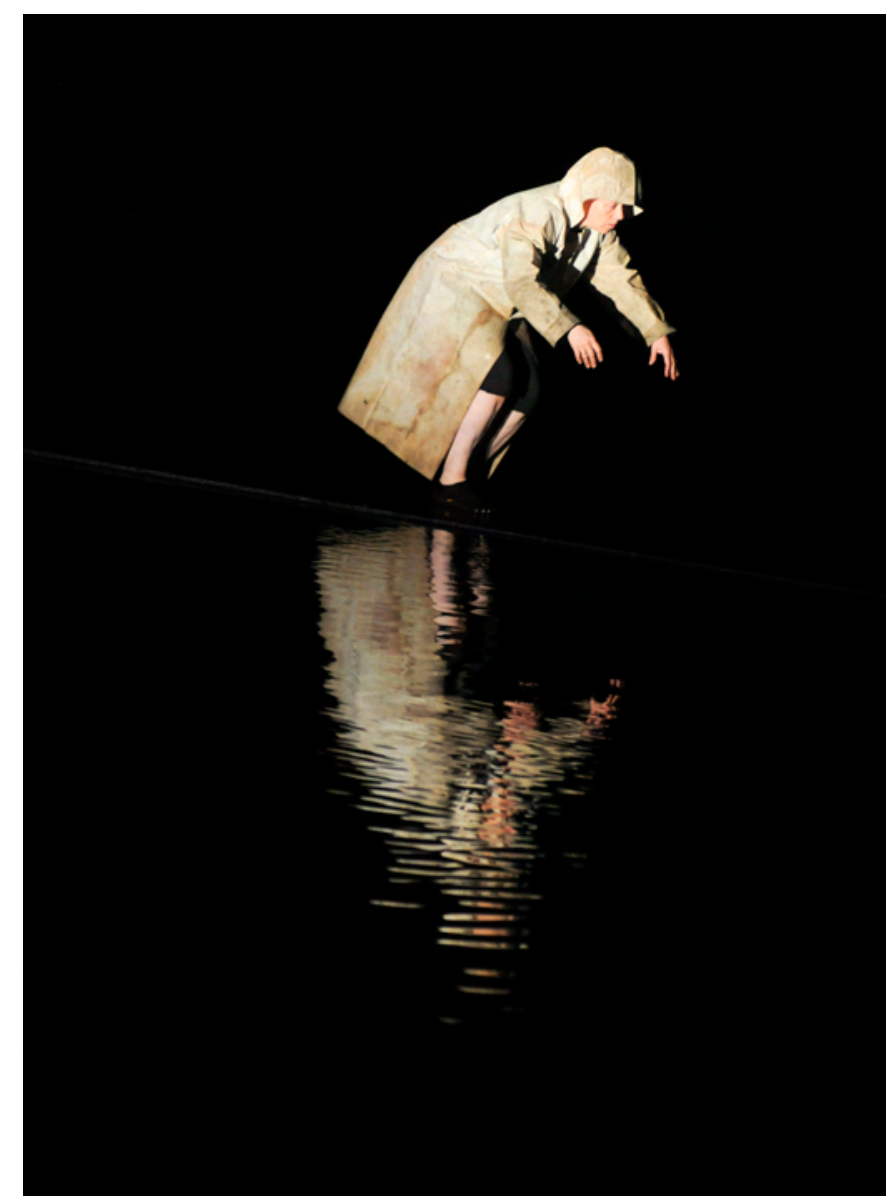

Figure 5: 'Float - Slipping Through Time'. Artwork by Tess de Quincey. Photo by Heidrun Löhr,

September 2010 .

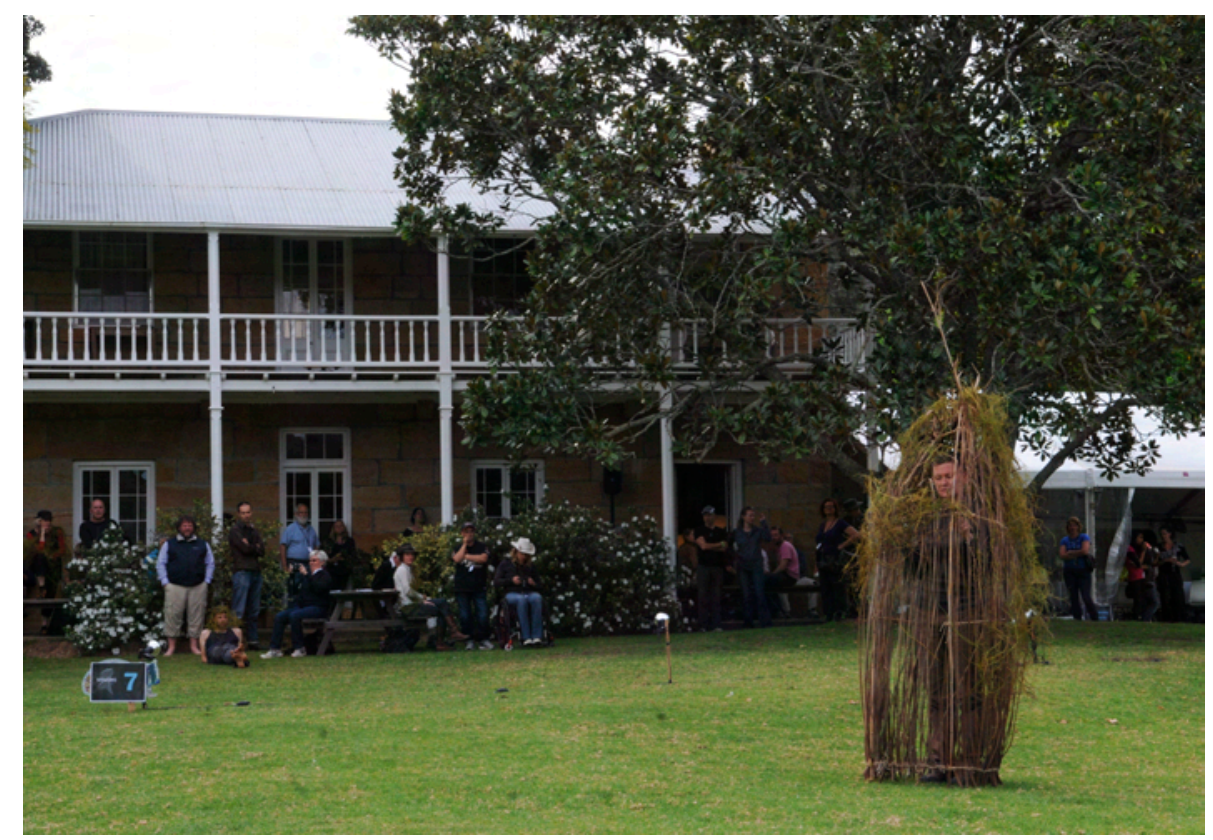

Figure 6: 'call, recall, respond'. Artwork by Barbara Campbell. Photo by Heidrun Löhr, September 2010. 


\begin{tabular}{|c|c|}
\hline \multicolumn{2}{|l|}{ Three glimpses } \\
\hline What makes a place? & Glimpse 2. \\
\hline $\begin{array}{l}\text { As a social scientist, and a human geographer, I am interested in } \\
\text { people and place. What inspires me is the relationships between lives } \\
\text { and landscapes. }\end{array}$ & $\begin{array}{l}\text { Taken on a walk to the river. Not overlooking this time, but on the sand. } \\
\text { We sit on the river-wet sand. }\end{array}$ \\
\hline and landscapes. & They welcome us to the river. They ask the river and the spirits to \\
\hline $\begin{array}{l}\text { My work is reading, documenting, analysing, and writing. I work with } \\
\text { words and with stories. }\end{array}$ & $\begin{array}{l}\text { welecome us and protect us. Iney use language to welcome us to country. } \\
\text { Language that emerges from this place; that is this place. They use song } \\
\text { and dance of this place. Draw stories in the sand to tell of a meeting of }\end{array}$ \\
\hline $\begin{array}{l}\text { When I came here, to this bend in the river, I was struck by the layers } \\
\text { of stories in this place. The layers of stories that make this place. } \\
\text { - a tantalizing relation between things - the fluidity of paint and } \\
\text { floods, the drift of clouds and the artist's imagination and so on it } \\
\text { goes' (2007) }\end{array}$ & $\begin{array}{l}\text { I don't understand those words, but I hear, see, feel the story - with my } \\
\text { body. My toes in the wet river sand. Strong voices reverberate in my } \\
\text { chest. I shudder at the echo across the water. Breeze against my cheek. } \\
\text { Light changes to make me squint. My neck cranes to watch a raptor fly } \\
\text { above us, up the river. }\end{array}$ \\
\hline $\begin{array}{l}\text { - a concert in protest of sand mining on the river nearby - 'the } \\
\text { obvious comment that the noise and intrusion of the concert and } \\
\text { its audience seemed inconsistent with a protest against the noise } \\
\text { and intrusion of sand mining' (1981) }\end{array}$ & $\begin{array}{l}\text { We're told that we are now part of the story of this place. And we walk } \\
\text { through the drawing in the sand, to obscure it. } \\
\text { The river and country and language are fragile. }\end{array}$ \\
\hline $\begin{array}{l}\text { a young girl - Helen McKenzie - washing her pony in the river } \\
\text { after the Nowra Show, swept away. Her father, Kenneth, went to } \\
\text { help her, but both were drowned. The jacaranda behind you, } \\
\text { beside the homestead veranda, planted in their memory (1922) }\end{array}$ & $\begin{array}{l}\text { Stories, and place-making are about our bodily interactions with place. } \\
\text { It is with our bodies that we become part of the story of the river. And }\end{array}$ \\
\hline $\begin{array}{l}\text { a new house built of local sandstone and locally cut cedar. Lime } \\
\text { mortar made from shell deposits collected downstream, and } \\
\text { transported by river drogher to this site (1866) }\end{array}$ & that we are changed. \\
\hline - frequent floods 'do not appear ... to have prevented settlement & Glimpse 3. \\
\hline $\begin{array}{l}\text { and extension of property holdings' despite 'a number of houses } \\
\text { at Bundanon' being washed away (from 1838)' }\end{array}$ & $\begin{array}{l}\text { A group of people - artists, scholars, local folk with rich knowledges and } \\
\text { experience - gather at a bend in the river, just downstream from here. } \\
\text { To work on responses to this site. }\end{array}$ \\
\hline $\begin{array}{l}\text { So often in scientific enquiry - whether it be physical science or social } \\
\text { science - and particularly in environmental research, the focus of }\end{array}$ & How will this collaboration work, I wonder. What will be revealed? \\
\hline $\begin{array}{l}\text { investigation is the human impact on nature - on the river. And this is } \\
\text { important work. Understanding how human actions shape and change }\end{array}$ & And then, five weeks later, warm greetings in the same large room. \\
\hline nature is important. & Conversation over a stainless steel bench. Conversation over curry. \\
\hline $\begin{array}{l}\text { But there is more than this. How does the river shape us? How does the } \\
\text { place make us? This is a question not about impact, but about } \\
\text { interaction. It allows that the river has the ability, the strength, the } \\
\text { agency, to act on us. To shape our lives. It illumininates the idea that } \\
\text { human lives are not all-powerful; but malleable; fallible. }\end{array}$ & $\begin{array}{l}\text { Conversation over breakfast coffee. My fingers feel clay slip. I taste weedy } \\
\text { risotto. Il listen to the world with eyes covered; trusted guide beside me. } \\
\text { Twist string from red-hot poker fibre. Sit in a boat, floating downstream. } \\
\text { Gently handle a letter }-1963 \text { - an invitation, Mr Boyd, to meet the } \\
\text { Queen, and in the bottom corner, a a hoppoping list vanilla, cinnamonon. } \\
\text { walk among lantana and lucerne bales and cable ties. Conversation over a } \\
\text { kitchen table. }\end{array}$ \\
\hline A glimpse of the river. & These bodily experiences frame and shape my response to this place. \\
\hline $\begin{array}{l}\text { We walk out to a rock platform, high above the river. Looking upstream- } \\
\text { way west to the hills of the upper catchment. And the setting sun. And } \\
\text { around the corner, just out of view, eastward, and downstream, towards }\end{array}$ & Working at the edges of our disciplines; our techniques. \\
\hline $\begin{array}{l}\text { the sea. Where the water is salty. } \\
\text { An overarching story of the history of this region. Of timber-getters - } \\
\text { cedar, I think. Of pastoralism. The details pass me by. }\end{array}$ & $\begin{array}{l}\text { Responding to the liminal spaces between art and science. Between } \\
\text { histories - indigenous, settler. Between human stories and local } \\
\text { ecologies. A cultural ecology, perhaps. Or a more-than-human } \\
\text { community. }\end{array}$ \\
\hline $\begin{array}{l}\text { But what I do hear, much more clearly, is a personal story, a story of a life } \\
\text { told along the river. A childhood spent mucking around in the } \\
\text { headwaters. Camping. }\end{array}$ & $\begin{array}{l}\text { One thinker, Prof. Dipesh Chakrabarty, suggests that to understand our } \\
\text { social-natural condition - in the face of tremendous complexity - we } \\
\text { mustn't rely on one discipline; one technigue; one language. We should }\end{array}$ \\
\hline $\begin{array}{l}\text { Later, a little way downstream, falling in love. And further down the river } \\
\text { still, a proposal of marriage. Moving down, down towards the brackish }\end{array}$ & $\begin{array}{l}\text { use everything we have to think, investigate, communicate, learn and } \\
\text { learn to live in the world. }\end{array}$ \\
\hline $\begin{array}{l}\text { reaches, now managing this property here on the river. } \\
\text { Following the water downstream, the river tells a life's story. }\end{array}$ & $\begin{array}{l}\text { And what a time! Such willingness, opportunity, support, to challenge our } \\
\text { knowledge and practice. }\end{array}$ \\
\hline $\begin{array}{l}\text { Key moments are lived, and key lessons - respect, resilience, } \\
\text { responsibility - are learnt from country. From place. All that is needed in } \\
\text { life comes from the land. } \\
\text { The river mirrors a life. It tells one person's life story. Being in this place, }\end{array}$ & $\begin{array}{l}\text { When I came here to Bundanon, I wanted to try to record, somehow } \\
\text { capture or represent the stories of this place. To talk about how the } \\
\text { stories - the layers of stories - make places. }\end{array}$ \\
\hline over-looking this river, tells that story. & $\begin{array}{l}\text { And I still like this idea. Places are not objective things, that pre-exist } \\
\text { us and our actions. But we make places, through our stories. }\end{array}$ \\
\hline $\begin{array}{l}\text { But more than this one life is told. We all return to places, to the river - } \\
\text { bodily; physically. The river changes; our life changes; but there is }\end{array}$ & $\begin{array}{l}\text { But there is more than this. The places act on us. On our bodies. To } \\
\text { shape our stories and our lives. }\end{array}$ \\
\hline $\begin{array}{l}\text { continuity. We learn from country, and what we learn remains, and is } \\
\text { re-inscribed with each visit. }\end{array}$ & $\begin{array}{l}\text { If only we are open to listening and learning. If only we allow } \\
\text { ourselves to be surprised; to be challenged. }\end{array}$ \\
\hline
\end{tabular}

Figure 7: 'Three Glimpses'. A reading, written and performed by Leah Gibbs, September 2010.

(Notes: i. Peter Freeman, Heritage Plan; ii. D.Chakrabarty, 'Can global climate change change

history?', Public lecture, [Indian Ocean \& South Asia Research Network, University of Technology

Sydney, 18th August 2010].) 


\section{Endnotes}

${ }^{1}$ Bundanon Trust, 'Bundanon Trust', http://www.bundanon.com.au (Accessed 22nd March 2011)

2 S.Cant and N.Morris, 'Geographies of art and the environment', Social \& Cultural Geography, 7 (2006), pp.857-861; C.DeSilvey and K.Yusoff 'Art and geography: image and imagination' in A.Douglas, R.Huggett and C.Perkins, eds, Companion Encyclopaedia of Geography: from Local to Global (London, Routledge, 2007), pp.571-586; F.Driver, C.Nash and K.Prendergast, 'Landing: eight collaborative projects between artists + geographers', http://www.gg.rhul.ac.uk/VG/landing/texts/intro.html (Accessed 25th May 2011); C.Dwyer and G.Davies, 'Qualitative methods III: animating archives, artful interventions and online environments', Progress in Human Geography, 34 (2009), pp. 88-97; K.Foster and H.Lorimer, 'Some reflections on art-geography as collaboration', Cultural Geographies, 14 (2007), pp.425-432; H.Hawkins, 'Geography and art. An expanding field: Site, the body and practice', Progress in Human Geography, OnlineFirst (2012); M.Miles, 'Representing nature: art and climate change' Cultural Geographies, 17 (2010), pp.19-35; D.Tolia-Kelly, 'The geographies of cultural geography II: Visual culture', Progress in Human Geography, 36 (2012), pp.135-142

${ }^{3}$ J.Gabrys and K.Yusoff, 'Arts, Sciences and Climate Change: practices and politics at the threshold', Science as Culture, 21 (2012), pp.1-24

${ }^{4}$ DeSilvey and Yusoff, 'Art and geography'; D.Dixon, 'Creating the semi-living: on politics, aesthetics and the more-than-human' Transactions of the Institute of British Geographers, 34 (2009), pp.411-425; Gabrys and Yusoff 'Arts, Sciences'; Miles, 'Representing nature'

5 Gabrys and Yusoff, 'Arts, Sciences', p.4

${ }^{6}$ L.Head, 'More than human, more than nature: plunging into the river', Griffith Review, 31 (2011) p.43

${ }^{7}$ K.Foster and H.Lorimer, 'Some reflections on art-geography as collaboration', Cultural Geographies, 14 (2007), pp.425-432; M.Patchett and K.Foster, 'Repair work: surfacing the geographies of dead animals', Museum and Society, 6 (2008) pp.98-122; P.Phillips, 'Doing art and doing geography: the fieldwork/field walking project', Australian Geographer, 35 (2004), pp.151-159

8 M.Crang, 'Qualitative methods: touchy, feely, look-see?', Progress in Human Geography, 27 (2003) pp.494-504; R.Longhurst, E.Ho and L.Johnston, 'Using "the body" as an “instrument of research": kimch'i and pavlova', Area, 40 (2008), pp.208-217 
${ }^{9}$ Cant and Morris, 'Geographies of art'; D.Mulholland, H.Lorimer and C.Philo, 'Resounding: an interview with Drew Mulholland', Scottish Geographical Journal, 125 (2009) pp.379-400; Patchett and Foster, 'Repair work'; H.Hawkins, '"The argument of the eye"? The cultural geographies of installation art', Cultural Geographies, 17 (2010) pp.321-340; A.Rogers, 'Geographies of the Performing Arts: Landscapes, Places and Cities', Geography Compass, 6 (2012) pp.60-75

${ }^{10}$ H.Hawkins, 'Dialogues and Doings: sketching the relationships between geography and art', Geography Compass, 7 (2011) p.472

11 Patchett and Foster, 'Repair work'

12 Op. cit., p.107

${ }^{13}$ Op. cit., p.98

${ }^{14}$ In the UK, recent debate in this area has focused on the controversial 'impact agenda', stimulated by changes to the country's research assessment system (see R.Pain, M.Kesby and K.Askins, 'Geographies of impact: power, participation and potential', Area, 43 (2011) pp.183-188; T.Slater, 'Impacted geographers: a response to Pain, Kesby and Askins', Area, 44 (2012) pp.117-119; P.North 'Knowledge exchange, "impact" and engagement: exploring low-carbon urban transitions', Geographical Journal, (2013)). Other authors (including N.Castree (ed.), 'Research assessment and the production of geographical knowledge', Progress in Human Geography, 30 (2006) pp.747-782, and G.Williams, 'The disciplining effects of impact evaluation practices: negotiating the pressures of impact within an ESRC-DFID project', Transactions of the Institute of British Geographers, 37 (2012) pp.489-495) point to much broader and longer-standing discussions about impact and engagement with publics in other contexts and elsewhere. 15 Tolia-Kelly, 'Geographies of cultural geography', p.135 ${ }^{16}$ S.McGrath, The Artist and the River: Arthur Boyd and the Shoalhaven (Kensington, Bay Books Pty Ltd, 1982), p.62

17 Boyd in McGrath, Artist and the River, p.222

18 Anon., Arthur Boyd: Shoalhaven \& beyond, exhibition at Wollongong City Gallery, 18 October - 3 December 1995, Wollongong

19 Op. cit., no page

${ }^{20}$ B.Niall, The Boyds (Carlton, Melbourne University Press, 2002) 
${ }^{21}$ D.Bungey, Arthur Boyd: a life (Crows Nest, Allen \& Unwin, 2007), pp.504-5

22 Niall, The Boyds

${ }^{23}$ Bungey, Arthur Boyd, p.538

24 Bundanon Trust, Bundanon Trust

25 Op. cit.

${ }^{26}$ Peter Freeman Pty Ltd 'The Bundanon Trust Properties Heritage Management Plan', (Volumes $1 \& 2,2007$ )

${ }^{27}$ See T.Cohen, M.Cohen \& M.Leggett In press 'Ten Trenches: a science-art collaboration' Leonardo

${ }^{28}$ See S.J.Kermode, M.R.Gibling, B.G.Jones, T.J.Cohen, D.M.Price and J.S.Daley In press 'Determining the impact of the Holocene highstand at the coastal-fluvial interface, Shoalhaven River, southeastern Australia' Earth Surface Processes and Landforms ${ }^{29}$ Bundanon Trust, Bundanon Trust; see also Cohen et al. 'Ten Trenches'

${ }^{30}$ Bundanon Trust, program, June-September 2010

${ }^{31}$ Fiona Winning, pers. com., August 2010

32 Foster and Lorimer, 'Some reflections'

33 Op. cit., p.426

${ }^{34}$ Op. cit., p. 425

35 Op. cit., p. 427

36 One outcome of SiteWorks is the 'Love the River' campaign ('Love the River', http://www.southern.cma.nsw.gov.au/lovetheriver/index.php [Accessed May 2011]). Emerging directly from the Conversation, this campaign has been taken up by the Southern Rivers Catchment Management Authority, Shoalhaven City Council and the broader community. The response has differed from previous efforts to promote river health in the area, many of which are deemed to belong to an environmental cause, and as a result alienate those whose interests may be considered at odds with such a priority, including dairy farmers and recreational wake-boarders. 'Love the River' has provided Bundanon Trust with a way to be involved in community interests without being overtly political, and to unite the community around a cause to which is it formally committed. 
${ }^{37}$ See also Head, 'More than human', pp.37-43

38 K.Gelder and J.M.Jacobs, Uncanny Australia: sacredness and identity in a postcolonial nation (Carlton South, Melbourne University Press, 1998); L.Head and J.Atchison, 'Cultural ecology: emerging human-plant geographies', Progress in Human Geography, 33 (2009), pp.236-245; S.Lavau, 'The nature/s of belonging: performing an authentic Australian river', Ethnos, 76 (2011), pp.41-64; K.Mee and S.Wright 'Geographies of belonging' Environment and Planning A, 41 (2009), pp.772-779; P.Read, Belonging: Australians, Place and Aboriginal Ownership (Cambridge, Cambridge University Press, 2000).

39 SiteWorks, 'SiteWorks Field Day program' (2010)

${ }^{40}$ For discussion of food and eating as sensory and embodied research method see R.Longhurst, E.Ho and L.Johnston, 'Using the body as an "instrument of research": kimch'i and pavlova', Area, 40 (2008), pp.208-217

${ }^{41}$ SiteWorks, 'SiteWorks Field Day program'

42 Op. cit.

${ }^{43}$ Lavau 'Nature/s of belonging'

${ }^{44}$ L.Head, 'Decentring 1788: Beyond Biotic Nativeness', Geographical Research, 50 (2012) pp.166-178

45 D.Trigger, J.Mulcock, A.Gaynor and Y.Toussaint, 'Ecological restoration, cultural preferences and the negotiation of "nativeness'" in Australia', Geoforum, 39 (2008) pp.1273-1283

${ }^{46}$ Head, 'Decentring 1788', p.166

47 Bundanon CEO Deborah Ely, pers. com., March 2011

48 S.Feary and H.Moorcroft 'An Indigenous Cultural Heritage Management Plan for the Bundanon Trust Properties', August 2011

${ }^{49}$ S.Feary and H.Moorcroft 'Indigenous heritage management strategy: Bundanon Trust properties', progress report 7th February 2011

${ }^{50}$ N.Morris and S.Cant 'Engaging with place: artists, site-specificity and the Hebden Bridge Sculpture Trail' Social \& Cultural Geography, 7 (2006), pp.863-888

${ }^{51}$ Cant and Morris, 'Geographies of art', p. 859 
${ }^{2}$ L.Gibbs 'Water Places: cultural, social and more-than-human geographies of nature', Scottish Geographical Journal, 125 (2009), pp.361-2

53 The raft is constructed by Bundanon staff and SiteWorks participants, and 'floated' upstream by a wetsuit clad Property Officer, under cover of darkness.

${ }^{54}$ Interview with Min Tanaka, Butoh performer and developer of Body Weather. Published in Art Quarterly, Fall 2006. Min Tanaka/Rin Ishihara official website, http://www.min-tanaka.com/wp/?page id=910 (Accessed 15th December 2012) 55 SiteWorks, 'SiteWorks Field Day program'

56 Bundanon Trust, 'Alex Kershaw', http://www.bundanon.com.au/content/alexkershaw-0 (Accessed 22nd March 2011)

57 See also Trigger et al. 'Ecological restoration'

58 Head 'Decentring 1788', p.174

59 R.J.Hobbs, S.Arico, J.Aronson, J.S.Baron, P.Bridgewater, V.A.Cramer, P.R.Epstein, J.J.Ewel, C.A.Klink, A.E.Lugo, D.Norton, D.Ojima, D.M.Richardson, E.W.Sanderson, F.Valladares, M.Vilà, R.Zamora and M.Zobel 'Novel ecosystems: theoretical and management aspects of the new ecological world order', Global Ecology and Biogeography, 15 (2006) pp.1-7; R.J.Hobbs, E.Higgs and J.A.Harris 'Novel ecosystems: implications for conservation and restoration', Trends in Ecology and Evolution, 24 (2009) pp.599-605

${ }^{60}$ Foster and Lorimer, 'Art-geography' p.425

61 Op. cit., p.427

62 Patchett and Foster, 'Repair work', p. 116

63 Phillips, 'Doing art', p. 151; see also P.Phillips, 'fieldwork/fieldwalking PhD 20032006', (2003-2011), http://www.perditaphillips.com/index.php?option=com content\&task=view\&id=134\&I $\underline{\text { temid }=45}$ (Accessed March 2011)

${ }^{64}$ M.Martin and S.Ryan, eds, The Lachlan: blue-gold (Canberra, Environment Studio, National Institute of the Arts, Australian National University, 2003), p.2 ${ }^{65}$ Crang, 'Qualitative methods'; Longhurst et al., 'Using the body' ${ }^{66}$ Gibson-Graham and Roelvink, 'Economic ethics', p.342 67 Op. cit., p. 325 
${ }^{68}$ H.Lorimer, 'Caught in the nick of time: archives and fieldwork' in D.DeLyser, S.Herbert, S.Aitken, M.Crang and L.McDowell, eds, The Sage Handbook of Qualitative Geography (London, Sage, 2010), p.269

${ }^{69}$ H.Hawkings, "'The argument of the eye"? The cultural geographies of installation art', Cultural Geographies, 17 (2010), pp.321-340

70 Gibson-Graham and Roelvink, 'Economic ethics', p.342

${ }^{71}$ Lorimer, 'Caught in the nick of time'

72 Tolia-Kelly, 'Geographies of cultural geography', p.135

73 Dwyer and Davies, 'Qualitative methods', p.95 